DOI https://doi.org/10.36059/978-966-397-117-9/97-119

\title{
CRIMINAL LEGAL POLICY IN COUNTERACTION TO CRIMES AGAINST OWNERSHIP AS A BASIS FOR OWNERSHIP PROTECTION IN UKRAINE
}

\section{Dorokhina Yu. A.}

The issue represented in the name of the given subsection is very urgent, but complex at the same time because criminal legal policy as for crimes against ownership is the field of human and social life activity, having the aim of orientation of public development by determining general goals and approving directions of ownership protection by criminal legal means. Unfortunately, today there are no clearly formed concepts, structure, tasks, principles and levels of such policy in legal doctrine of Ukraine.

Rare works of scientists dedicated to this range of problems can not give an opportunity to obtain a holistic idea about the said legal phenomenon. However, in view of the fact that Ukraine has undertaken to adapt own legal system to the legal system of the European Union, this process, in our opinion, should be started, first of all, from scientific theoretical development of relevant legal structures and, firstly, the ones requiring improvement within the national legal theory. It is the abovementioned that explains relevancy and urgent necessity for the development of doctrinal provisions of criminal legal policy as for crimes against ownership.

We should begin with the issue that includes the concept of policy. The words of Carl Schmitt are demonstrative in this case: "one can rarely come across a clear definition of the political. In most cases this word is used only in a negative way, in contrast to the concepts in such antithesis as ... "policy and law", and in law it is antithesis again "policy and civil law" etc. $><$ In special literature there are many such descriptions of the political, which, however, as they have no political polemical sense, can be clear only due to practical technical interest in legal or administrative settlement of single cases. Such definitions, meeting the need of practice, in fact, seek only a practical means for separation of different actual 
obligations arising inside the state in its legal practice but the aim of these definitions is not a common definition of the political as such"1.

Most of researches note that the policy specificity is connected with the ability to ensure integrity of society; agree different groups of interests, regulate public relations effectively. Policy content can be revealed by forming its essential features: 1) policy is a field of power relations, relations as for power, its organization, division between different groups of interests, determination of direction of a state activity and its institutions; 2) policy is a way of public life organization based on integration of various interests, their agreement on the basis of common interest, uniting all society members; implementation and prevalence of common interest in contrast to the needs of private individuals, groups etc; 3) police is an activity of elite and leaders concerning management and administration of public development processes at all levels by using state authorities ${ }^{23}$.

Policy as a social phenomenon is a diverse, dynamic thing which forms the main directions in the development of legal and other fields of social existence and state. The formation of such directions of the development in a legal field allows determining its main priorities, settling law-making activity, and this way ensuring the creation of effective mechanism of legal regulation. The above mentioned can be achieved by forming the legal policy which is called for balance and settle the legal life.

Legal policy is a multilevel legal institution, which includes: 1) ideas, principles, goals, tasks that form a certain conceptual basis of the policy in the field of law, and their absence destroys the process of building up a system; 2) legal and political conditions developed over a certain period of time; 3) strategies and tactics of legal development; 4) means of legal policy.

Improvement of legal policy should lead to changes and facilitate the development of social reality. In turn, legal science should "not only

\footnotetext{
${ }^{1}$ Шмитт К. Понятие политического. М., 2011

${ }^{2}$ Мухаев, Р. Т. Политология : учеб. для студентов вузов / Р. Т. Мухаев. - 3-е изд., пераб. и доп. М.: ЮНИТИ-ДАНА, 2005.

${ }^{3}$ Новий тлумачний словник української мови: у 3 Т. / Уклад. В. Яровенко, О. Коліушко. - К.: Аконіт, 1998. - Т. 3. - С. 514-542., с. 514.

${ }^{4}$ Политология: учеб пособие для техн. вузов / М. А. Василик, И. П. Вишнякова-Вишневецкая, Ю. Г. Вилунас и др.; под ред. М. В. Василика. - 4-е изд., перераб. и доп. - Спб.: Пионер; М.: Астрель: ACT, 2005.
} 
comment and systematize legal phenomena and processes, but logically "count" possibilities of improvement and transformation of legal reality, foresee possibilities of its development" . The main aim of state legal policy is a stable effective development of a legal system.

An important component of legal policy is counteraction to crime, which is designed to reduce its level and ensure the state, meeting the needs of protecting society from crime ${ }^{6}$. State policy in the field of counteraction of crime consists of types, features of which are determined by the tasks, subject and methods of achieving the results necessary for society. Such types are: criminal law, criminal procedure, criminalexecutive and criminological policy ${ }^{7}$.

The concept of "criminal legal policy" is used and interpreted in a special literature ambiguously. In legal science, there are different views on the issue of how the concept itself should sound: "criminal policy" or "criminal legal policy". Most contemporary authors use the concept of "criminal legal policy" to determine the policy related to formation of a system of rules of substantial criminal law, determination of boundaries of the criminal and non-criminal, problems of effectiveness of substantial criminal law implementation, etc." 8

The Criminal Code reflects a stable, predictable and effective criminal policy of the state, consolidating its directions, ${ }^{9}$ formed on the basis of grouping of objects of criminal infringement (the criterion for such division is the generic object of crime) and determined by the level of significance of public relations regulated by them.

P. L. Fris, V. I. Borisov distinguish directions according to the fields of criminal law policy, distinguishing, among others, criminal legal policy in counteraction to crimes against ownership ${ }^{10}$. We can not absolutely agree with the above wording, since any direction is in the field of a certain defined group of public relations. The direction of criminal legal

\footnotetext{
5 Керимов Д.А. Методология права (предмет, функции, проблемы философии права). - М., 2000., c. 284 .

${ }^{6}$ Борисов В. І. Сучасна політика держави у сфері боротьби зі злочинністю та ії кримінальноправовий напрям // Право України. - 2012. - № 1-2. - С. 232.

7 Коробеев А. И. Советская уголовно-правовая политика: проблемы криминализации и пенализации. - Владивосток, 1987. - С. 46-48.

8 Борисов В.І., Фріс П.Л. Ефективність кримінально-правової політики / Вісник Асоціації кримінального права України, 2014, № 1(2). - С. 1-18, с. 5

9 Тацій В. Боротьба зі злочинністю на початку XXI ст.- проблема сьогодення / В. Тацій // Щорічник українського права: зб. наук. праць. - 2009. - № 1. - С. 215-228., с. 217.

10 Борисов В.І., Фріс П.Л. Ефективність кримінально-правової політики / Вісник Асоціації кримінального права України, 2014, № 1(2). - С. 1-18, с. 5.
} 
policy determines its goal-oriented action. The field of policy implementation characterizes the very range of public relations, through which the direction of criminal legal policy is going. Criminal legal policy as for counteraction to crimes against ownership is the direction of criminal legal policy, the actions of which are in the field of public ownership relations and aimed at securing public relations, inherent in ownership relations, from socially dangerous infringements by means of criminal law.

The model of criminal legal policy as for counteraction to crimes against ownership, as the basis of its doctrine, should include the following components: the object, the subject matter, subjects, purpose, scope, vectors and principles. Its development is determined by the following factors: 1) today there is no single system approach to ownership protection; 2) requirements for improving the protection of ownership are being increased, taking into account its distribution to separate objects of protection; 3) there is no algorithm for improving ownership protection under the conditions of globalization and virtualization of the world in the postmodern era.

Evaluating ownership as the highest value and, objects requiring criminal legal protection respectively, the criminal legal policy as for counteraction to crimes against ownership is designed to create a system of political and legal measures aimed at securing ownership from socially dangerous infringements. Criminal legal policy as for counteraction to crimes against ownership should be considered as a policy whose system of measures ensures the proper development, timely implementation and effective exercise of norms of substantial criminal law, aimed at securing ownership from socially dangerous infringements.

The object of the criminal legal policy as for counteraction to crimes against ownership is the safety of those public relations from socially dangerous infringements covered by the action of such policy. Certainly, the scope of criminal legal policy as for counteraction to crimes against ownership is not limited to public relations in the field of ownership. The spectrum of such relations is much wider.

Objects of property are in a state of continuous interaction with other objects and subjects, and such interaction is accompanied by emergence of new forms and types of criminal infringements. Therefore, the process of searching and obtaining new knowledge about crimes in the ownership 
field and the most effective measures to ensure the protection of ownership by criminal law means are of great significance.

In order to develop or create a program of certain measures that meet the requirements of the present, first of all, it is necessary to make the definitions clear. Correct definition of essence of the ownership concept is an important precondition for its successful and full existence.

Legal literature recognizes inter-branch nature of the ownership institution ${ }^{11}$. Since ownership is the object of not only civil, but also labor, administrative, financial, criminal legal relations, this category is of common law, and accordingly its concept should be the single one for the legal system. Unfortunately, today ownership, as an integral part of the national legal system, is broken by branch sciences and national legislation into parts. In order to prevent the splitting of the concept integrity, it is necessary to strive for its content to be inter-integral. The heterogeneous understanding of this category is a major obstacle to improving criminal legislation aimed at ownership protection, eliminating collisions in criminal law, and developing a modern criminal legal policy in the field of counteraction to crimes against ownership.

During the history, the path to understanding the ownership concept in law was ambiguous. In pre-revolutionary jurisprudence, ownership right was seen as a complete domination of a person over a thing ${ }^{12}$. For the founders of the Soviet legal school an economic view of ownership was typical ${ }^{13}$. The fact that the economic relations of ownership, having acquired legal regulation, became ownership right relations was generally recognized $^{14} 151617$.

Pre-revolutionary criminal law placed the emphasis on the protection of not the nature of ownership right, but different ways of its use. The criminal conclusions of that time criminalized actions against the illegal use, possession and disposal of someone else's property. Offenses against

\footnotetext{
11 Мазаев В. Д. Публичная собственность в России. Конституционные основы / В. Д. Мазаев. Москва, 2004. - 380 с., с. 132.

12 Шершеневич Г. Ф. Учебник русского гражданского права (по изданию 1907 г.). М., 1995. С. $165-166$.

13 Рыженков А. Я., Черноморец А. Е. Очерки теории права собственности (прошлое и настоящее). - Волгоград, 2005. - 675 с., с. 605.

${ }^{14}$ Братусь С.Н. Предмет и система советского гражданского права. - М., 1963. - 196 с., с. 21-23.

${ }_{16}^{15}$ Венедиктов А.В. Государственная социалистическая собственность. - М., 1948.-834 с., с. 22-28.

16 Маслов В.Ф. Основные проблемы права личной собственности в период строительства коммунизма в СССР. -Харьков: изд-во ХГУ 1968-320 с., с. 7.

17 Червоний Б.С. Методологічні проблеми регуляванне відносин власності в законодавстві України // Економіко-правові проблеми трансформації відносин власності в Україні. К., 1997. -С. 42-44., с. $42-44$.
} 
ownership were reduced to a violation of the procedure and ways of its use, namely, "to four main types: 1) unauthorized acquisition; 2) unauthorized use; 3) unauthorized disposal and 4) acquisition of known someone else's things, or ... stealing of someone else's property"18.

Having approved the objects of protection, pre-revolutionary criminal law adapted the ownership institution to them. The diversity of subjects (owner, lessee, creditor, etc.) was simplified in the same way; each of them had an independent legal status and an individual relation to ownership. Theorists of criminal law, guided by the fact that none of them affected the content of unlawful acts ${ }^{19}$, took those properties of subjects as a basis that were sufficient for the concept of "plunder". And it was characterized by a close connection, which contained only the subject of plunder and someone else's property. For the criminal law of that time a person, physically connected with the thing, was enough. There was no owner in this chain. In this view, L. S. Belogrits-Kotlyarevsky noted that it was important for the theory of criminal law that the property was in the person's possession ${ }^{20}$. V. D. Spasovich added: "it is not important whether it is an owner, lessee, or dishonest possessor; one can steal property even from a thief" ${ }^{21}$. M. D. Sergeevsky, agreeing with the position above, noted: "for the composition of theft it is not importation on which ground a person owns a thing which has been stolen from him",22.

The opinions mentioned became priority in the theory of criminal law of that time that proved the fact of adaptation of Roman conception of individual property possession according to which "legal protection is followed a property possessor not an owner, not depending whether he is given authority in the form of ownership right or in other form of individual use of things" 23 .

\footnotetext{
${ }^{18}$ Неклюдов Н. А. Руководство к Особенной части русского уголовного права / Н. А. Неклюдов. Санкт-Петербург, 1876. - Т. 2. - 564 с., с. 2.

19 Чебышев-Дмитриев А. Русское уголовное право. Особенная часть / А. Чебышев-Дмитриев. Санкт-Петербург, 1866. - С. 19.

20 Белогриц-Котляреский Л. С. Учебник русского уголовного права : учебник / Л. С. БелогрицКотляреский. - Киев ; Харьков, 1903. - 870 с., с. 403.

21 Замечания на проект Особенной части Уголовного уложения / Сост. членами СанктПетербургского Замечания на проект Особенной части Уголовного уложения / сост. членами СанктПетербургского юридического общества: В. Д. Спасовичем, С. А. Андреевским, Г. В. Гантовером, А. А. Герке, Е. И. Утиным. - Санкт-Петербург, 1887. - С. 180.

${ }^{22}$ Сергеевский Н. Д. Конспект Особенной части русского уголовного права / Н. Д. Сергеевский. Санкт-Петербург, 1884. - С. 61.

${ }^{23}$ Муромцев С. А. Гражданское право Древнего Рима / С. А. Муромцев. - Москва, 2003. - С. 124.
} 
M. A. Nekludov outlined the basic categories of the institutions of crimes against ownership and pointed out: "ownership - a set of external objects and property rights belonging to the person" 24 . As a result, the subject matter of the crime was both ownership and property. The difference between them consisted only in the fact that the property includes things that have a market value, and the ownership has a personal value (subjective).

Scientific approaches to ownership were also expressed by other scholars (V. D. Spasovich, S. O. Andriivsky, G. V. Gantower, A. A. Gerke, E. I. Kachin), who understood this category only because of possession of the thing ${ }^{25}$. In their opinion, ownership, as evidence of an ideal connection between a person and things, can not be the object of criminal legal protection. For protection it must have an actual connection of property with a person.

Thus, pre-revolutionary criminal law protected the rights of not legal, but the actual owner, user and property manager. This approach to ownership was the basis of the pre-revolutionary theory of crimes against ownership. In this theory, ownership (as well as the owner himself) was an abstract concept. As a result, the institution of ownership was simplified. Pre-revolutionary lawyers identified the possessor with the owner and the ownership with the property. Ownership right was replaced by possession, as well as other material rights.

The system of Soviet criminal law preserved uncertainty of ownership institution provision. Theories of Soviet criminal law emphasized the property as "protection of physical prevalence of a person over a thing" 26 . It was determined by the fact that, from the point of view of Marxism, ownership is a definite form of public relations as for appropriation and possession of material wealth.

Ownership was characterized by the presence of such person's authority over a thing that was recognized by society and regulated by social norms. The owner disposed of the thing by his authority, in his interests. For him, the thing is his, for non-owners - not theirs. Since the

\footnotetext{
${ }^{24}$ Неклюдов Н. А. Руководство к Особенной части русского уголовного права / Н. А. Неклюдов. Санкт-Петербург, 1876. - Т. 2. - 564 с., с.1

25 Замечания на проект Особенной части Уголовного уложения / Сост. членами СанктПетербургского Замечания на проект Особенной части Уголовного уложения / сост. членами СанктПетербургского юридического общества: В. Д. Спасовичем, С. А. Андреевским, Г.В.Гантовером, А. А. Герке, Е. И. Утиным. - Санкт-Петербург, 1887. - С. 3.

${ }^{26}$ Жалинский А. Э. О материальной стороне преступления / А. Э. Жалинский // Уголовное право. 2003. - № 3. - C. 29.
} 
authority of the person (the owner) over the thing is impossible without the fact that other persons (who are not the owners of the thing) treated it as someone else, property was understood as relations between people about things. On one side is the owner who treats things as his personal, on the other - non-owners, that is, all other persons who are obliged to treat it as someone else, therefore, they must refrain from any infringements on someone else's thing and at the will of the owner to have this thing.

The Soviet criminal legal policy in the field of ownership protection was aimed at protecting not ownership relations, but the procedure of property use. The norms of the Criminal Code consolidated this position, recognizing not ownership, but property relations as the object of their protection. The concept of property crimes proceeded from the fact that a person committed a crime violated the subjective rights of citizens to things where the subject matter of such infringements was someone else's movable property in the form of physical things. Later on, other objects of legal protection were also distinguished: a) ownership rights; b) property rights; c) "property as a whole". The concept of "property as a whole" was considered on the one hand as a set of property rights, on the other hand, as a set of values that the subject has ${ }^{27} 28$.

Representatives of the Soviet school distinguished in ownership "two main abstract aspects: economic and legal" 29 . Separate scholars of Soviet criminal law understood under the ownership production relations, whose members distribute material goods, appropriates means of production and products of labor 30313233 34, namely, in general, they assigned economic and legal content 3536 to the ownership, where "economic" means the

27 Клепицкий И. А. Собственность и имущество в уголовном праве / И. А. Клепицкий // Государство и право. - 1997. - №. 5. - С. 75

${ }_{28}$ Тюнин В. И. Преступления экономические в Уголовном уложении 1903 года / В. И. Тююнин // Правоведение. - 2000. - № 2. - С. 235-243.

${ }^{29}$ Пашуканис Е. Б. Избр. произведения по общей теории права и государства / Е. Б. Пашуканис. Москва, 1980. - С. 110.

${ }^{30}$ Пинаев А. А. Уголовно-правовая борьба с хищениями / А. А. Пинаев. - Минск, 1975. - С. 13.

31 Владимиров В. А. Ответственность за корыстные посягательства на социалистическую собственность / В. А. Владимиров, Ю. И. Ляпунов. - Москва, 1986. - С. 10.

${ }^{32}$ Тенчов Э. С. Квалификация преступлений против собственности / Э. С. Тенчов. - Иваново, 1981. - C. 5.

33 Советское уголовное право. Особенная часть: учебник / под ред. П. И. Гришаева, Б. В. Здравомыслова. - Москва, 1988. - С. 100.

${ }^{34}$ Курс уголовного права : учебник : в 5 т. / под ред. Г. Н. Борзенкова, В.С. Комиссарова. - Москва, 2002. - Т. 3. Особенная часть. - С. 387.

35 Дуюнов В. К Комментарий к Уголовному кодексу Российской Федерации (Постатейный) / В. К. Дуюнов ; отв. ред. ЈI. ЈI. Кругликов. - Москва, 2005. - 300 с. 
actual, and "legal" is a legal acquisition of property by a particular person As a result, the ownership was never recognized by a criminal law science in the status of an independent object of protection.

With the development of economic turnover, ownership relations have become much more complicated. There was a new look at the acts that caused property damage, but did not fall under the category of "crimes against ownership", but the above did not lead to a revision of the main definitions.

Modern national law science still continues to feel the powerful influence of Soviet legal ideology. Many legal concepts (including the concept of ownership protection) are still living in Ukrainian legal science. We believe that these theories and concepts can not find a place in the legal theory of the country, which proclaimed itself a democratic, law-governed and social state, therefore, the revision and formation of new modern approaches are essential.

In the state proclaiming the protection of ownership, economic (ownership) and legal (ownership right) meaning of ownership should not be separated. They exist in an inseparable unity ${ }^{37}$. Today, most countries of the world adhere to this concept.

One can find a proof of the above in the Civil Code of France in Article 544, where the following definition is given: «La propriete est le droit de jour et disposer des choses...» (Ownership right is the right to use and dispose of things...) ${ }^{38}$. The term of «La propriete» can be translated as both "ownership" and "ownership right" 39 .

The same approach can be seen in civil law of Spain. Article 348 of the Civil Code of Spain defines the ownership right as follows: "La propriedad es el derecho de gozar в diesponer de una cosa...» (The ownership is a right to use and dispose of a thing..." 40 . The term of «La propriedad» can be translated as "ownership" and "ownership right" 41 .

\footnotetext{
36 Лопашенко Н. А. Преступления в сфере экономики. Авторский комментарий к уголовному закону (Раздел VIII УК РФ) / Н. А. Лопашенко. - Москва, 2006. - 680 с.

${ }^{37}$ Пацурківський Ю.П. Основні підходи до визначення поняття та природи власності в цивільних правовідносинах Науковий вісник Чернівецького університету. 2013. Випуск 682. Правознавство., C. 60-64.

38 Code civil. Titre 11-De la propriete [Electronic resource]. - Mode of access: http://www.civilites.com/cctv/L2T2C1.htm.

${ }^{39}$ Великий французько-український словник «Larousse»: Близько 420000 одиниць перекладу, слів та словосполучень / Бусел В.; Перун, 2011. - 1504 с., с. 680.

${ }^{40}$ Codigo civil (espanol). Ed. Aranzadi. - Pamplona, 1998. - 162 c.

${ }^{41}$ Іспансько-український, українсько-іспанський словник + граматика: 70000 слів. Автор-укладач: ОльгаМазура. - Донецьк: ГлоріяТрейд, 2009., с. 410.
} 
In the Civil Code of Argentine they use the following term to define ownership right «El dominio»: «Art. 1882. El dominio es el derecho real que otorga todas facultades de usar, gozar в disponer de una cosa...» (Ownership right is a material right giving all powers on possession, use and disposal of a thing... $)^{42}$. The term «El dominio» is translated as power, authority, and possession ${ }^{43} 44$.

The identical conclusion can be made from civil-legal norms of Italy. The third book of the Civil Code contains norms dedicated to the ownership right ${ }^{45}$. The term «la proprieta» is translated as "ownership", and "ownership right" 46 .

Civil law of California and Quebec province do not distinguish the ownership and ownership right as well. According to Article 654 of the Civil Code of California the ownership right can be understood as follows: "The ownership of a thing is the right of one or more persons to possess and use it to the exlusion of othersı ${ }^{47}$. The same norm is contained in Article 947 of the Civil Code of Quebec: «Ownership is the right to use, enjoy and dispose of property fully and freely...» ${ }^{48}$. The terms of «ownership» and «property» ${ }^{49}$ do not correspond to Ukrainian concept of ownership ${ }^{50}$. Such approach can be found in the Codes of Portugal (Article 1305) and Switzerland (Article 641).

Article 1 of the first protocol to the European Convention has the following: "Every natural and legal entity has the right to the peaceful possession of his property. No one can be deprived of his property except in the public interest and subject to the conditions provided for by law and by the general principles of international law". Protocol № 11 to the Convention was amended in the article mentioned which obtained the

\footnotetext{
${ }^{42}$ Proyecto de codigo civil de 1998 (de la Republica Argentina) [Electronic resource]. - Mode of access: rittp//alterini/org/civil.htm.

${ }^{43}$ Іспансько-український, українсько-іспанськийсловник + граматика: 70000 слів. Автор-укладач: ОльгаМазура. - Донецьк: ГлоріяТрейд, 2009., с. 174.

44 Латинсько-український словник / Мирослав Трофимук, Олександра Трофимук - Львів: Вид-во ЛБА, 2001., с. 225.

45 Codice Civile Italiano R. D. 16 marzo 1942, n. 262 Approvazione del testo del Codice Civile (Pubblicato nella edizione straordinaria della Gazzetta Ufficiale, n. 79 del 4 aprile 1942). - P. 136.

46 Словникіталійсько-російсько-український, українсько-російсько-італійський / Уклад. КатеринаЗоленкова, ОленаЗоленкова, ДієгоРудзанте. - Тернопіль: Богдан, 2008., с. 368.

47 Civil code of California [Electronic resource]. - Mode of access: http://www.leginfo.ca.gov./cgibin/displeycode. $\mathrm{en} / 14 / \mathrm{t} 2 / \mathrm{c} 1$.

${ }^{48}$ Civil code of Quebec [Electronic resource]. - Mode of access: www.lexum.umontreal.ca/ccq/

49 Англо-українськийсловник- EnglishUkrainian Dictionary. Близько 120000 слів: у 2-х томах / Уклад. М. І. Балла. - Київ: Освіта, 1996., с. 788.

${ }_{50}$ Шимон С. І. Майнові права в контексті сучасних концепцій права власності у цивілістиці / С. І. Шимон // Часопис Київського університету права. - 2012. - С. 192-195, с. 192.
} 
name of «protection of property», and its content in the official translation obtained quite a different wording: "Every natural and legal entity has the right to the peaceful possession of his property. No one can be deprived of his ownership..." At the same time in English text of the Convention the following formulation is used: "Every natural or legal person is entitled to the peaceful enjoyment of his possessions. No one shall be deprived of his possessions except in the public interest and subject to the conditions provided for by law and by the general principles of international law" 51. So, the difference in terms exists only in Ukrainian translation.

On the basis of this we can assume that in civil law and legislation in many countries of the world there is no clear distinction between ownership and ownership rights. The European doctrine puts the concept of "ownership right" in the term of "ownership" as if it involves an understanding of "ownership right". Hence, ownership is understood in a broad sense.

Analyzing the practice of the European Court in the context of the European Convention, it can be seen that the concept of "ownership" is constantly expanding. This is undoubtedly supported by the position of the European Court, which consistently repeats that "ownership" in the sense of the Convention and the Protocol to it is an autonomous phenomenon which in no way is connected with its national understanding and has an interpretation independent of the national ${ }^{52}$.

Today, Ukraine has come close to the need to adapt the current legislation to the European Union (EU) norms. The development of criminal legal policy and the harmonization of Ukrainian legislation, in particular with regard to criminal legal policy as for crimes against ownership, with the basic principles of EU law is a necessary element in this field.

Modern national science of civil law treats property in two ways: in the narrow one as a set of things and in the broader one as a set of things, property rights and obligations. This approach led to the fact that, in relation to Section 6 of the Special Part of the Criminal Code of Ukraine in the concept of ownership, a lawmaker introduced an ambiguous approach. In the case of understanding in the broad sense, it is directly

\footnotetext{
51 Protocol 1 to the ECHR [Electronic resource]. - Mode of access: http://echr-online.info/right-toproperty-article-1-of-protocol-1-to-the-echr/introduction/

${ }_{52}$ Мірошниченко О. А. Право власності у розумінні Європейського суду з прав людини (загальна характеристика) [Електронний ресурс] / О.А. Мірошниченко. - Режим доступу: file:///C:/Users/SZ740/Downloads/FP_index.htm_2013_2_57.pdf
} 
enshrined in the disposition of the articles (Article 190 of the Criminal Code of Ukraine defines not only property but also the right to it). In the dispositions of other articles (Articles 185, 186, 187 of the Criminal Code of Ukraine), a lawmaker does not make any instructions regarding extended interpretation, so the concept of ownership in the narrow sense should be used. This causes the main problems of qualification.

Now, as never before, there is an urgent need to revise, improve and formulate a new approach to a universal, inter-integral concept of ownership, which does not oppress existing and emerging relations, but can cover as much as possible their diversity. Determining the concept of ownership one should be based on the features of protection, used by criminal legal relations, etc. If absolute protection and resistance to infringement from the third parties can be considered primary, then objects of ownership should be all objects that society wants and can defend by criminal legal means. Consolidating the ownership as an object of protection from criminal infringements can cover both the static state (refraining from unlawful actions) and the active behavior of subjects (use of right, fulfillment of obligations).

This in no way reduces the role of other elements (components). However, as in each system (and the criminal legal policy as for counteraction to crimes against ownership is an appropriate system characterized by all the features of the system), something must be the basic, determinant, so to speak, the driving force. In this system, the concept of ownership fulfills such function.

An analysis of conceptions of understanding the concepts as well as content of ownership, studied by us, allows making some important conclusions. Ownership is an autonomous phenomenon that should be interpreted independently of its national understanding ${ }^{53}$ and includes three components: the first one is the everyday (social) perception at the level of common sense, where ownership is something (material) belonging to anyone. The second one is legal, where ownership includes property, property rights and ownership right. The third one is economic, and more precisely, political-economic, as a system category, where property is not the person's relation to any object, but the relations between people regarding the appropriation (alienation) of this object.

\footnotetext{
${ }^{53}$ Мірошниченко О. А. Право власності у розумінні Європейського суду з прав людини (загальна характеристика) [Електронний ресурс] / О.А. Мірошниченко. - Режим доступу: file:///C:/Users/SZ740/Downloads/FP_index.htm_2013_2_57.pdf
} 
Moreover, appropriation and alienation are categories, that express the objective contradiction between the two parties of the content of ownership, and therefore with the elimination of alienation the appropriation is eliminated and, accordingly, the relations of ownership themselves $^{54}$. In all three components there are criminal legal features ${ }^{55}$ : in the first case, the ownership appears as a subject of a criminal infringement; the second and third ones are the object on which the crime is directed.

Proceeding from the broad interpretation of the concept of ownership, it is reasonable to understand under the object of criminallegal policy as for counteraction to crimes against ownership the public relations that form the state of safety from:

1) Socially dangerous infringements on property;

2) Socially dangerous infringements on property rights;

3) Socially dangerous infringements on ownership right.

These objects should be reflected in the norms of Section VI of the Special Part of the Criminal Code of Ukraine, taking into account the trends in the development of modern social life, which determines the necessity of extending the regime of ownership to intangible objects as well.

The proof of the above can be found in the rational logic of modern thinking and economic development of mankind. This leads to the necessity to revise and modernize the legal concept of "a thing". In our opinion, the national civil law is behind the requirements of the present. The time has passed when under the "things" people understood material objects that literally surrounded a person. The development of society (first of all, its technical progress) has led to the fact that the interpretation of the concept of the subject matter of crimes against ownership as material objects of the outside world restricts this category. In some cases, the crime may also be directed to "intangible" benefit.

The American researcher Jeremy Rifkin in "The Age of Access" notes: firstly, real estate is devalued from the point of view of its functional purpose; and secondly, impressions (a paid-for-experience) are becoming goods in addition to material objects (things). Those that are

\footnotetext{
${ }^{54}$ Никитин А.М. Криминологические проблемы развития отношений собственности при переходе к рынку [Электронный ресурс]: Дис... .Д-ра юрид. наук:12.00.08. - М. : РГБ, 2003. - 365 с., с. 37.

55 ЖалинскийА.Э.О соотношении уголовного и гражданского права в сфере экономики // Государство и право. 1999. - № 12. -С. 47-52.
} 
considered prestigious and commercially replicable: exotic lifethreatening travels or a club card that provides access to the "limited circle" are demonstrative "goods" of the modern economy; thirdly, the reorientation of the economy described above leads to a shift in the emphasis in legal capacity of the owner - from legal capacity of possession prevailing before to legal capacity of use finding its manifestation in access. It is no coincidence that the book was called "Access - Das Verschwinden des Eigentums" in the German translation, since ownership of material benefits, that is, ownership in its classical sense is gradually disappearing ${ }^{56}$.

"Unsubstantial" property is considered as an object of ownership right in foreign legal systems; in particular, such view extends to the rights to industrial ownership objects, the rights to objects of "financial and commercial ownership" (right to claim money, bonds, bills, checks, shares, bills of lading, etc. $)^{57}$. In the countries of the Anglo-American legal system, the objects of material legal relations, along with traditional things, include so-called "things on request": monetary obligations; negotiable documents; securities, shares, bonds; copyright; patent rights; trademarks etc.

Even today national court practice considers crimes, the subject of which is, for example, non-cash money as free withdrawal of someone else's property. The lawmaker also (although partly) supported the abovestated position by consolidating the norms aimed at electric power protection in the Criminal Code (Article 188-1 of the Criminal Code of Ukraine). However, many issues still require improvement and regulatory consolidation.

The above mentioned is definitely being actualized due to the fact that today the role of ownership is changing. Information ownership plays a special role. The world community has entered a new era - the era of information society. Today, a daily life of mankind depends to a certain extent on telecommunication technologies used in almost all domains of human activity (energy, water supply, finance, trade, science, education, etc.).

\footnotetext{
${ }^{56}$ Войниканис Е.А., Якушев М.В. Информация. Собственность. Интернет : традиция и новеллы в современном праве. - М.: Волтерс Клувер. - 2004. - 146 с., с. 24-39.

${ }^{57}$ Гражданское и торговое право зарубежных государств. Учебник: В 2-х томах. Т. 1 / Буднева Г. Н., Васильев Е. А., Грибанов А. В., Зайцева В. В., и др.; Отв. ред.: Васильев Е. А., Комаров А. С. - 4-е изд., перераб. и доп. - М.: Международные отношения, 2006. - 560 с. - С. 314-315.
} 
With the development of information space, it is necessary to intensify the efforts of the society to protect it from criminal infringements, a set of which already has its own, well-known worldwide name - cybercrime. It has become widespread and under the present conditions it constitutes one of the most dangerous threats of Ukrainian society. The rapid development of telecommunications and global computer networks has created conditions facilitating the commission of crimes against ownership and form new compositions. Criminals are increasingly using new ways to infect computers with dangerous programs which assist in obtaining criminal profits.

According to the NCR Report (Norton Cybercrime Report), the number of victims of cybercrime in 2012 was 341 million, and in 2015 594 million people, therefore, these figures increase annually. About $70 \%$ of Internet users at least once faced with fraud in the network, and at least $10 \%$ of them, suffered from phone frauds ${ }^{58}$.

Today, in our opinion, most of the crimes against ownership provided for in Section VI of the Special Part of the Criminal Code of Ukraine may be committed by using harmful computer programs and software and hardware connected to the computer network. The exception is only crimes, the way of which is connected with the direct contact of the offender with the victims, as well as a significant part of crimes, where only materialized property can be the subject. Due to the fact that crimes against ownership are committed using information and communication technologies, they do not change the object of their infringement, but there is an attachment of an additional object in the form of relations in the field of information technology.

The possibility of the existence of such object itself is rather disputable, at the same time, it is obvious that the use of modern computer technologies increases and qualitatively changes the social danger from crime. In this regard, the system of norms, consolidating crimes against ownership, needs to be improved, since it does not fully take into account modern cyber threats.

Offenses against ownership committed with the use of information and communication technologies are characterized by such feature as "mass nature", that is, the commission of a crime against a large and, as a rule, indefinite circle of victims. This leads to the fact that it is practically

582015 Internet Security Threat Report http://www.symantec.com/security_response/publications/ whitepapers.jsp 
impossible to accurately determine the amount of the damage, and sometimes, this amount is too small to bring to criminal liability. Thus, the question arises as to whether harm can be a sign of a crime that reflects the nature and extent of social danger? Definitely not.

Unlike information crimes, the main property of crimes against ownership committed with the use of computer networks is that the subject of the crime uses computer networks as tool or means of committing a crime. That is what adds to such crimes unique properties that are not typical of other infringements. Thus, the concept of crimes against ownership committed with the use of computer networks can be defined as a combination of criminal acts prohibited by law, the manner of which requires the mandatory use of such networks as a tool or means. In addition, the content of the object of these crimes may be different and not related to public relations that arise in the information field.

The impact of globalization in the field of criminal law is observed in all countries and applies to all elements of criminal policy: criminal legal science, criminal law, practice of its application, definition of ways and forms of fighting against crime, development of special prophylactic, preventive measures. However, the influence of globalization processes on these elements is diverse. Criminal legal regulation of various domains of life of the society and the state under the conditions of globalization can be considered from different sides, at different points of view, taking into account the content of criminal and legal provisions of the General and Special Parts, but necessarily within those elements that form criminal legal policy. This is the provisions of the criminal law science in the doctrine of crimes against ownership, on punishment and other measures to counteract crimes against ownership; this is the rule-making, legislative activity, the system and activities of law enforcement bodies, etc.

Since the time of emergence of criminal law, its main questions have been and are - what to punish, who to punish and how to punish? It seems that in this triad, the first two problems tend to be influenced by the processes of globalization to the greatest extent. It is here that one can observe a certain universalization in the form of unification and harmonization. As for the institution of punishment, these questions are the prerogative of national criminal law. Although some issues of punishment are also considered internationally.

The globalization of economy is accompanied by the international nature of crimes against ownership; it generates organized transnational crime in this field. Transnational organized crime groups, interacting with 
local criminal elements, lead to an increase in a number of different types of crimes against ownership at the local level. Accordingly, crime, motivation and forms of unlawful infringement on ownership have changed.

For the successful development of a law-governed, democratic state, the creation of an effective system of protection of ownership and, above all, by criminal legal means is crucial. Protection of ownership of one person inevitably reflected in the system of public relations of ownership and of the state as a whole. On the contrary, lack of a state criminal legal policy to counteract crimes against ownership causes a rise in social tension, resulting in a consistently high level of such infringements. Therefore, the leading idea of criminal legal policy as for counteraction to crimes against ownership is the formation and implementation of norms for the protection of ownership from socially dangerous infringements by means of substantial criminal law.

\section{CONCLUSIONS}

The criminal legal policy as for counteraction to crimes against ownership is an independent direction of criminal legal policy of Ukraine, which should cover all directions of the latter in order to achieve a state of complete protection and safety of ownership by criminal legal means.

Taking into account the properties of ownership as the object of criminal legal policy as for counteraction to crimes against ownership, as well as the properties of its components, the doctrinal level of criminal legal policy as for counteraction to crimes against ownership constitutes a teaching of the basic laws, tactics and strategies of securing a positive dynamics of protection of ownership from socially dangerous infringements by means of substantial criminal law. It should provide a general influence on the formation of other levels of criminal legal policy as for to counteraction to crimes against ownership, as well as properties, to be their scientific basis, to implement successful achievements of other levels, including them in the doctrine of criminal law and law in general.

\section{SUMMARY}

The present state of scientific development of criminal legal policy is analyzed. It is noted that taking into account commitment to adapt Ukrainian legal system to the European Union legal system, this process should be initiated, first of all, by the improvement of corresponding legal structures within the national legal theory. The urgency and necessity of 
revision of doctrinal provisions of the criminal legal policy as for counteraction to crimes against ownership is substantiated.

Key words: ownership, criminal legal policy, counteraction to crimes, crimes against ownership.

\section{REFERENCES}

1. Шмитт К. Понятие политического. М., 2011

2. Мухаев, Р. Т. Политология : учеб. для студентов вузов / Р. Т. Мухаев. - 3-е изд., пераб. и доп. - М.: ЮНИТИ-ДАНА, 2005.

3. Новий тлумачний словник української мови: у 3 Т. / Уклад. В. Яровенко, О. Коліушко. - К.: Аконіт, 1998. - Т. 3. - С. 514-542., c. 514 .

4. Политология: учеб пособие для техн. вузов / М. А. Василик, И. П. Вишнякова-Вишневецкая, Ю. Г. Вилунас и др.; под ред. М. В. Василика. - 4-е изд., перераб. и доп. - Спб.: Пионер; М.: Астрель: АСТ, 2005.

5. Керимов Д.А. Методология права (предмет, функции, проблемы философии права). - М., 2000., с. 284.

6. Борисов В. І. Сучасна політика держави у сфері боротьби зі злочинністю та їі кримінально- правовий напрям // Право України. 2012. - № 1-2. - С. 232.

7. Коробеев А. И. Советская уголовно-правовая политика: проблемы криминализации и пенализации. - Владивосток, 1987. C. $46-48$.

8. Борисов В.І., Фріс П.Л. Ефективність кримінально-правової політики / Вісник Асоціації кримінального права України, 2014, № 1(2). - С. 1-18, с. 5 .

9. Тацій В. Боротьба зі злочинністю на початку XXI ст.проблема сьогодення / В. Тацій // Щорічник українського права: зб. наук. праць. - 2009. - № 1. - С. 215-228., с. 217.

10. Борисов В.І., Фріс П.Л. Ефективність кримінально-правової політики / Вісник Асоціації кримінального права України, 2014, № 1(2). - С. 1-18, с. 5

11. Мазаев В. Д. Публичная собственность в России. Конституционные основы / В. Д. Мазаев. - Москва, 2004. - 380 с., c. 132.

12. Шершеневич Г. Ф. Учебник русского гражданского права (по изданию 1907 г.). М., 1995. С. 165-166. 
13. Рыженков А. Я., Черноморец А. Е. Очерки теории права собственности (прошлое и настоящее). - Волгоград, 2005. - 675 с., c. 605 .

14. Братусь С.Н. Предмет и система советского гражданского права. - М., 1963. - 196 с., с. 21-23.

15. Венедиктов А.В. Государственная социалистическая собственность. - М., 1948.-834 с., с. 22-28.

16. Маслов В.Ф. Основные проблемы права личной собственности в период строительства коммунизма в СССР. Харьков: изд-во ХГУ $1968-320$ с., с. 7.

17. Червоний Б.С. Методологічні проблеми регуляванне відносин власності в законодавстві України // Економіко-правові проблеми трансформації відносин власності в Україні. К., 1997. -С. 42-44., c. $42-44$.

18. Неклюдов Н. А. Руководство к Особенной части русского уголовного права / Н. А. Неклюдов. - Санкт-Петербург, 1876. T. $2 .-564$ c., c. 2.

19. Чебышев-Дмитриев А. Русское уголовное право. Особенная часть / А. Чебышев-Дмитриев. - Санкт-Петербург, 1866. - С. 19

20. Белогриц-Котляреский Л. С. Учебник русского уголовного права : учебник / Л. С. Белогриц-Котляреский. - Киев ; Харьков, 1903. - 870 c., c. 403.

21. Замечания на проект Особенной части Уголовного уложения / Сост. членами Санкт-Петербургского Замечания на проект Особенной части Уголовного уложения / сост. членами СанктПетербургского юридического общества: В. Д. Спасовичем, С. А. Андреевским, Г. В. Гантовером, А. А. Герке, Е. И. Утиным. Санкт-Петербург, 1887. - С. 180.

22. Сергеевский Н. Д. Конспект Особенной части русского уголовного права / Н. Д. Сергеевский. - Санкт-Петербург, 1884. C. 61 .

23. Муромцев С. А. Гражданское право Древнего Рима / С. А. Муромцев. - Москва, 2003. - С. 124.

24. Неклюдов Н. А. Руководство к Особенной части русского уголовного права / Н. А. Неклюдов. - Санкт-Петербург, 1876. - Т. 2. -564 c., c. 1.

25. Замечания на проект Особенной части Уголовного уложения / Сост. членами Санкт-Петербургского Замечания на проект Особенной части Уголовного уложения / сост. членами Санкт- 
Петербургского юридического общества: В. Д. Спасовичем, С. А. Андреевским, Г. В. Гантовером, А. А. Герке, Е. И. Утиным. Санкт-Петербург, 1887. - С. 3.

26. Жалинский А. Э. О материальной стороне преступления / А. Э. Жалинский // Уголовное право. - 2003. - № 3. - С. 29.

27. Клепицкий И. А. Собственность и имущество в уголовном праве / И. А. Клепицкий // Государство и право. - 1997. - №. 5. C. 75 .

28. Тюнин В. И. Преступления экономические в Уголовном уложении 1903 года / В. И. Тююнин // Правоведение. - 2000. - № 2. C. 235-243.

29. Пашуканис Е. Б. Избр. произведения по общей теории права и государства / Е. Б. Пашуканис. - Москва, 1980. - С. 110.

30. Пинаев А. А. Уголовно-правовая борьба с хищениями / А. А. Пинаев. - Минск, 1975. - С. 13.

31. Владимиров В. А. Ответственность за корыстные посягательства на социалистическую собственность / В. А. Владимиров, Ю. И. Ляпунов. - Москва, 1986. - С. 10.

32. Тенчов Э. С. Квалификация преступлений против собственности / Э. С. Тенчов. - Иваново, 1981. - С. 5.

33. Советское уголовное право. Особенная часть : учебник / под ред. П. И. Гришаева, Б. В. Здравомыслова. - Москва, 1988. - С. 100.

34. Курс уголовного права: учебник: в 5 т. / под ред. Г. Н. Борзенкова, В.С. Комиссарова. - Москва, 2002. - Т. 3. Особенная часть. - С. 387.

35. Дуюнов В. К Комментарий к Уголовному кодексу Российской Федерации (Постатейный) / В. К. Дуюнов ; отв. ред. JI. JI. Кругликов. - Москва, 2005. - 300 с.

36. Лопашенко Н. А. Преступления в сфере экономики. Авторский комментарий к уголовному закону (Раздел VIII УК РФ) / Н. А. Лопашенко. - Москва, 2006. - 680 с.

37. Пацурківський Ю.П. Основні підходи до визначення поняття та природи власності в цивільних правовідносинах Науковий вісник Чернівецького університету. 2013. Випуск 682. Правознавство., C. 60-64.

38. Code civil. Titre 11-De la propriete [Electronic resource]. - Mode of access: http://www.civilites.com/cctv/L2T2C1.htm. 
39. Великий французько-український словник «Larousse»: Близько 420000 одиниць перекладу, слів та словосполучень / Бусел В.; Перун, 2011. - 1504 с., с. 680.

40. Codigo civil (espanol). Ed. Aranzadi. - Pamplona, 1998. - 162 c.

41. Іспансько-український, українсько-іспанський словник + граматика: 70000 слів. Автор-укладач: ОльгаМазура. - Донецьк: ГлоріяТрейд, 2009., с. 410.

42. Proyecto de codigo civil de 1998 (de la Republica Argentina) [Electronic resource]. - Mode of access: rittp//alterini/org/civil.htm.

43. Іспансько-український, українсько-іспанськийсловник + граматика: 70000 слів. Автор-укладач: ОльгаМазура. - Донецьк: ГлоріяТрейд, 2009., с. 174.

44. Латинсько-український словник / Мирослав Трофимук, Олександра Трофимук - Львів: Вид-во ЛБА, 2001., с. 225.

45. Codice Civile Italiano R. D. 16 marzo 1942, n. 262 Approvazione del testo del Codice Civile (Pubblicato nella edizione straordinaria della Gazzetta Ufficiale, n. 79 del 4 aprile 1942). - P. 136.

46. Словникіталійсько-російсько-український, у українськоросійсько-італійський / Уклад. КатеринаЗоленкова, ОленаЗоленкова, ДієгоРудзанте. - Тернопіль: Богдан, 2008., с. 368.

47. Civil code of California [Electronic resource]. - Mode of access: http://www.leginfo.ca.gov./cgi-bin/displeycode.

48. Civil code of Quebec [Electronic resource]. - Mode of access: www.lexum.umontreal.ca/ccq/ en/14/t2/c1.

49. Англо-українськийсловник- EnglishUkrainian Dictionary. Близько 120000 слів: у 2-х томах / Уклад. М. І. Балла. - Київ: Освіта, 1996., c. 788.

50. Шимон С. I. Майнові права в контексті сучасних концепцій права власності у цивілістиці / С. І. Шимон // Часопис Київського університету права. - 2012. - С. 192-195, с. 192.

51. Protocol 1 to the ECHR [Electronic resource]. - Mode of access: http://echr-online.info/right-to-property-article-1-of-protocol-1-to-theechr/introduction/

52. Мірошниченко О. А. Право власності у розумінні Європейського суду 3 прав людини (загальна характеристика) [Електронний ресурс] / О. А. Мірошниченко. - Режим доступу: file:///C:/Users/SZ740/Downloads/FP_index.htm_2013_2_57.pdf

53. Мірошниченко О. А. Право власності у розумінні Європейського суду 3 прав людини (загальна характеристика) 
[Електронний ресурс] / О. А. Мірошниченко. - Режим доступу: file:///C:/Users/SZ740/Downloads/FP_index.htm_2013_2_57.pdf

54. Никитин А.M. Криминологические проблемы развития отношений собственности при переходе к рынку [Электронный ресурс]: Дис... .д-ра юрид. наук:12.00.08.-М. : РГБ, 2003.- 365 с., с. 37

55. ЖалинскийА.Э.О соотношении уголовного и гражданского права в сфере экономики // Государство и право. 1999. - № 12. C. 47-52.

56. Войниканис Е.А., Якушев М.В. Информация. Собственность. Интернет : традиция и новеллы в современном праве. - М.: Волтерс Клувер. - 2004. - 146 с., с. 24-39.

57. Гражданское и торговое право зарубежных государств. Учебник: В 2-х томах. Т. 1 / Буднева Г. Н., Васильев Е. А., Грибанов А. В., Зайцева В. В., и др.; Отв. ред.: Васильев Е. А., Комаров А. С. 4-е изд., перераб. и доп. - М.: Международные отношения, 2006. 560 c. - C. $314-315$.

58. 2015 Internet Security Threat Report http://www.symantec.com/ security_response/publications/whitepapers.jsp

59. Фріс П. Л. Кримінально-правова політика України: дис. докт. юрид. наук / Павло Львович Фріс. - Івано-Франківськ: Прикарпатський юридичний інститут внутрішніх справ, 2005. 381 с., с. $37-38$

60. Бабаев M. М. Криминологические основы российской уголовно-правовой политики / M. М. Бабаев // Современная уголовная политика: поиск оптимальной модели: материалы VII Российского конгресса уголовного права (31 мая - 1 июня 2012 г.). - Москва: Проспект, 2012. - С. 318-340., с. 325

61. Концепція реформування кримінальної юстиції України, затверджена Указом Президента України від 8 квітня 2008 року № 311/2008 / [Електронний ресурс]. - Режим доступу: http://zakon4.rada.gov.ua/laws/show/311/2008

62. Сапун В. О. Социалистическое правосознание и реализация советского права: учеб. пособие / Валентин Андреевич Сапун. Владивосток: Изд-во Далневост. ун-та, 1984. - 181 с, с. 114

63. Разгильдиев Б. Т. Уголовно-правовая политика: назначение, виды / Б. Т. Разгильдиев // Современная уголовная политика: поиск оптимальной модели: материалы VII Российского конгресса уголовного права (31 мая - 1 июня 2012 года). - Москва: Проспект, 2012. - C. $229-238$. 
64. Панов М. Правова політика як універсальний феномен соціального буття / Микола Панов, Людмила Герасіна // Право України. - 2001. - № 8. - С. 36- 40.

65. Эстрин А. Я. Эволюция советской уголовной политики / А. Я. Эстрин // Основы и задачи советской уголовной политики. - Л.: ЛГУ, 1929. - $184 \mathrm{c.}$

66. Мальцев В. В. Принципы уголовного права и их реализация в правоприменительной деятельности / Василий Васильевич Мальцев. - СПб.: Юридический центр Пресс, 2004. - 692 с.

67. Борисов B.I., Фріс П.Л. Поняття кримінально-правової політики / Вісник Асоціації кримінального права України, 2013, № 1(1). - C. 13-31, c. 20.

\section{Information about the author:} Dorokhina Yu. A.

Doctor in Law, Assistant Professor, Professor at the Department of Special Legal Disciplines of the Educational-Scientific Humanitarian Institute of the V. I. Vernadsky Taurida National University 